\title{
PCR Detection and RFLP Differentiation of Botrytis Species Associated with Neck Rot of Onion
}

Karsten Nielsen, Department of Crop Protection, Danish Institute of Agricultural Sciences, Research Center Flakkebjerg, 4200 Slagelse, Denmark; David S. Yohalem, Department of Crop Protection, Danish Institute of Agricultural Sciences, Research Center Flakkebjerg, 4200 Slagelse, Denmark; Dan Funck Jensen, Department of Plant Biology, The Royal Veterinary and Agricultural University,1841 Frederiksberg, Denmark

\begin{abstract}
Nielsen, K., Yohalem, D. S., and Jensen, D. F. 2002. PCR detection and RFLP differentiation of Botrytis species associated with neck rot of onion. Plant Dis. 86:682-686.

Botrytis aclada and other Botrytis spp. can cause neck rot on onions, a storage disease that normally is very difficult to detect at harvest using traditional isolation techniques. Sequence characterized amplified region primers (BA2f/BA1r) were designed based on a previously cloned and amplified DNA fragment for direct amplification of isolates of Botrytis spp. associated with neck rot of onions. Digestion of the polymerase chain reaction (PCR) amplification product with the restriction enzyme ApoI makes it possible to distinguish the five groups: Botrytis aclada types AI and AII (B. allii); B. byssoidea; B. squamosa; and B. cinerea. The detection limit was 1 to $10 \mathrm{pg}$ of pure fungal DNA. It was possible to detect $B$. aclada with the PCR method in artificially inoculated onion bulb tissue and in mature onion leaves showing no symptoms of the disease. The availability of a sensitive and specific PCR detection and identification method for Botrytis onion neck rot pathogens should facilitate ecological studies of this group of onion pathogens.
\end{abstract}

Additional keywords: Allium, Botryotinia, SCAR, UP-PCR

Onions (Allium cepa L.) are attacked by at least seven Botrytis species $(5,6)$. Of these, Walker (27) distinguished three that cause neck rots: $B$. aclada Fresen (syn. $B$. allii Munn), causal agent of sclerotial neck rot; Botrytis byssoidea J.C. Walker (teleomorph Botryotinia allii (Sawada) W. Yamamoto), causal agent of mycelial neck rot (27); and Botrytis squamosa J.C. Walker (teleomorph Botryotinia squamosa Vien.Bourg), causal agent of small sclerotial neck rot of white onion cultivars (27). $B$. squamosa is better known as the causal agent of onion leaf blight. Botrytis cinerea Pers.:Fr. (teleomorph Botryotinia fuckeliana (de Bary) Whetzel) can cause leaf spots and discoloration of onion bulbs (7), and is occasionally found in rotted neck tissues. Of these onion pathogens, $B$. aclada is most commonly associated with onion neck rot disease (10-12). However, in some years $B$. byssoidea has been more frequently isolated than $B$. aclada from diseased onion bulbs in the United Kingdom (23). B. aclada may be seedborne, but most infections by $B$. aclada are reported to occur in the field $(11,12)$. Tichelaar $(26)$

Corresponding author: David S Yohalem
E-mail: David.Yohalem@agrsci.dk

Accepted for publication 14 February 2002.

Publication no. D-2002-0412-03R

(c) 2002 The American Phytopathological Society demonstrated that B. aclada can grow asymptomatically in apparently healthy onion leaves and is not normally observed in the field until close to harvest. First symptoms of neck rot normally occur after 1 to 2 months of storage $(11,12,26)$.

Traditional identification of Botrytis spp. relies on isolation followed by morphological examination $(11,22,23)$. Both time and mycological expertise are required for identification, due to frequently observed variation in the genus. It has been demonstrated, with the aid of universally primed polymerase chain reaction (UP-PCR) DNA fingerprints that more than half of the $B$. byssoidea isolates obtained from culture collections were incorrectly identified (17). Most of the misidentified isolates had DNA fingerprints that matched those of $B$. squamosa. An enzyme-linked immunosorbent assay (ELISA) detection method has been developed for detection of B. aclada (8). However, the antibody strongly crossreacts with $B$. cinerea, and the two other Botrytis pathogens responsible for onion neck rot, B. byssoidea and B. squamosa, are not detected using this method. Moreover, B. aclada consists of two genetically distinct subgroups (AI and AII). Morphological, cytological, and molecular data show that B. aclada type AII is a polyploid hybrid of $B$. aclada AI and B. byssoidea $(17,19,25)$.

PCR-based methods have been successfully applied for sensitive and rapid detection of plant pathogenic fungi $(2,14,15)$. To facilitate the rapid appraisal of interactions between Botrytis spp. and biocontrol agents in field experiments (D. S. Yohalem, unpublished data), we developed a rapid and reliable PCR-based method for detection of latent infections of Botrytis spp. in onion tissues. This detection method would also be useful for epidemiological studies of the neck rot disease. Recent epidemics of neck rot attributed to infested seed lots have been reported in the United States, and the lack of standardized procedures for detection and differentiation of the causal agents has been noted (1). A PCR-based detection system could be used for evaluation of the storage potential of an onion crop and to test onion seed and onion sets for latent infection by Botrytis spp. to ensure healthy sowing-planting material.

A UP-PCR DNA fragment from $B$. aclada associated with neck rot of onions was cloned and sequenced (19). Based on these sequences, a PCR detection method for rapid and reliable monitoring of Botrytis neck rot organisms was designed and is presented here. The method exclusively detects Botrytis spp. neck rot-associated isolates, and it can distinguish among the five neck-rotting types of Botrytis.

\section{MATERIAL AND METHODS}

Fungal isolates. Fungal isolates (Table 1) were maintained on potato dextrose agar (PDA) (Difco Laboratories, Detroit, MI). For long-term preservation, isolates were either stored in a $15 \%$ glycerol suspension at $-80^{\circ} \mathrm{C}$, or they were grown on PDA in sealed tubes and stored at $4^{\circ} \mathrm{C}$. For production of conidia, Botrytis isolates were grown in 9-cm plastic petri dishes containing PDA for 14 days at $21^{\circ} \mathrm{C}$ under near UV light. Spores were harvested by adding $2 \mathrm{ml}$ of sterile $\mathrm{H}_{2} \mathrm{O}$ to the plates and gently scraping off the spores with a sterile scalpel. Spore suspensions were filtered through a $34-\mu \mathrm{m}$ nylon mesh to remove fungal mycelium. All neck rot-associated Botrytis isolates used in this study are virulent on onion bulbs (16).

Plant material and inoculation methods. Onion bulbs ('Centurion') were obtained from a local onion grower. Bulbs were sliced into disks, $0.5 \mathrm{~cm}$ thick, with a sterile knife, and the two outermost scales were discarded. The remaining scales were cut into pieces $1 \mathrm{~cm}$ in length. Four pieces were placed in a $9-\mathrm{cm}$ petri dish, inocu- 
Table 1. Fungal isolates used in this study

\begin{tabular}{|c|c|c|c|c|c|c|}
\hline \multirow[b]{2}{*}{ Isolates } & \multirow[b]{2}{*}{ Source $^{\mathbf{a}}$} & \multirow[b]{2}{*}{ Original no. } & \multirow[b]{2}{*}{ Origin } & & $\begin{array}{r}\text { Diagnostic band } \\
\text { PCR amp }\end{array}$ & $\begin{array}{l}\text { restriction digested } \\
\text { tion product }\end{array}$ \\
\hline & & & & Isolated from & ITS1-4 \#SphI ${ }^{\mathrm{b}}$ & BA2f-BA1r \#ApoI ${ }^{\mathrm{c}}$ \\
\hline Botrytis aclada $(\mathrm{AI})^{\mathrm{d}} \mathrm{BA} 1$ & 1 & BA1 & Denmark & Bulb of A. cepa & 3 & $413 \mathrm{bp}$ \\
\hline BA2 & 1 & BA2 & Denmark & Bulb of A. cepa & 3 & $413 \mathrm{bp}$ \\
\hline BA3 & 2 & MUCL 8 & Belgium & Bulb of A. cepa & 3 & $413 \mathrm{bp}$ \\
\hline BA8 & 2 & MUCL 3037 & Canada & Bulb of A. серa & 3 & $413 \mathrm{bp}$ \\
\hline BA9 & 2 & MUCL 3106 & USA & Bulb of A. сера & 3 & $413 \mathrm{bp}$ \\
\hline BA13 & 2 & MUCL 8415 & Germany & Bulb of A. сера & 3 & $413 \mathrm{bp}$ \\
\hline BA17 & 2 & MUCL 18967 & England & A. ascalonicum & 3 & $413 \mathrm{bp}$ \\
\hline BA18 & 3 & B4065 & UK & Bulb of A. серa & 3 & $413 \mathrm{bp}$ \\
\hline BA19 & 3 & B4090 & UK & Bulb of A. сера & 3 & $413 \mathrm{bp}$ \\
\hline BA21 & 1 & 3-DK99 & Denmark & Bulb of A. серa & 3 & $413 \mathrm{bp}$ \\
\hline BA22 & 1 & 8-DK99 & Denmark & Bulb of A. cepa & 3 & $413 \mathrm{bp}$ \\
\hline BA28 & 2 & MUCL 3810 & Belgium & Bulb of A. сера & 3 & $413 \mathrm{bp}$ \\
\hline BA29 & 2 & MUCL 20329 & Belgium & A. schoenoprasum & 3 & $413 \mathrm{bp}$ \\
\hline BA30 & 4 & CBS 260.71 & Denmark & Bulb of A. cepa & 3 & $413 \mathrm{bp}$ \\
\hline BA33 & 5 & SAL003 & Japan & A. сера & 3 & $413 \mathrm{bp}$ \\
\hline BA35 & 5 & SAL005 & Japan & A. сера & 3 & $413 \mathrm{bp}$ \\
\hline BA36 & 5 & SAL006 & Japan & A. сера & 3 & $413 \mathrm{bp}$ \\
\hline B. aclada (AII) BA4 & 2 & MUCL 403 & Netherlands & Bulb of A. cepa & 2 & $413+298 b p$ \\
\hline BA5 & 2 & MUCL 99 & USA & Bulb of A. cepa & 2 & $413+298 \mathrm{bp}$ \\
\hline BA6 & 2 & MUCL 961 & Belgium & Bulb of A. cepa & 2 & $413+298 b p$ \\
\hline BA7 & 2 & MUCL 1150 & Norway & Bulb of A. cepa & 2 & $413+298 \mathrm{bp}$ \\
\hline BA10 & 2 & MUCL 3109 & Japan & Leaf of $A$. сера & 2 & $413+298 b p$ \\
\hline BA11 & 2 & MUCL 3614 & Egypt & Bulb of A. cepa & 2 & $413+298 b p$ \\
\hline BA12 & 2 & MUCL 494 & Denmark & A. ascalonicum & 2 & $413+298 b p$ \\
\hline BA14 & 2 & MUCL 9114 & Netherlands & Leaf of A. cepa & 2 & $413+298 b p$ \\
\hline BA16 & 2 & MUCL 18868 & Scotland & Bulb of A. серa & 2 & $413+298 b p$ \\
\hline BA20 & 6 & $61-2$ & USA & A. сера & 2 & $413+298 b p$ \\
\hline BA23 & 1 & 13-DK99 & Denmark & Bulb of A. cepa & 2 & $413+298 b p$ \\
\hline BA24 & 2 & MUCL 1105 & USA & $\ldots$ & 2 & $413+298 b p$ \\
\hline BA25 & 2 & MUCL 3528 & $\ldots$ & $\ldots$ & 2 & $413+298 b p$ \\
\hline BA26 & 2 & MUCL 3537 & & $\ldots$ & 2 & $413+298 b p$ \\
\hline BA27 & 2 & MUCL 3556 & UK & Bulb of A. сера & 2 & $413+298 b p$ \\
\hline BA31 & 5 & SAL001 & Japan & A. сера & 2 & $413+298 b p$ \\
\hline BA32 & 5 & SAL002 & Japan & A. сера & 2 & $413+298 b p$ \\
\hline BA34 & 5 & SAL004 & Japan & A. сера & 2 & $413+298 b p$ \\
\hline B. byssoidea BB1 & 2 & MUCL 94 & USA & Bulb of A. cepa & 2 & $298 \mathrm{bp}$ \\
\hline BB5 & 2 & MUCL 9113 & Netherlands & A. сера & 2 & 298 bp \\
\hline BB6 & 3 & B3730 & UK & A. porrum & 2 & 298 bp \\
\hline B. cinerea $\mathrm{BC} 1$ & 1 & $\mathrm{BC} 1$ & Denmark & Leaf of $A$. серa & + & $250 \mathrm{bp}$ \\
\hline BC3 & 2 & MUCL 3107 & USA & Leaf of A. сера & + & $250 \mathrm{bp}$ \\
\hline $\mathrm{BC} 4$ & 2 & MUCL 3647 & Kenya & Coffea arabica & + & $250 \mathrm{bp}$ \\
\hline BC5 & 2 & MUCL 9115 & Netherlands & Leaf of $A$. серa & + & $250 \mathrm{bp}$ \\
\hline BC6 & 2 & MUCL 10117 & Israel & Bulb of A. серa & + & $250 \mathrm{bp}$ \\
\hline BC7 & 2 & MUCL 21596 & Netherlands & Leaf of $A$. сера & + & $250 \mathrm{bp}$ \\
\hline BC8 & 6 & $61-34$ & USA & & + & $250 \mathrm{bp}$ \\
\hline B. squamosa BS2 & 2 & MUCL 3821 & Belgium & Leaf of $A$. сера & + & $269 \mathrm{bp}$ \\
\hline $\begin{array}{l}\text { BS6 } \\
\end{array}$ & 2 & MUCL 28710 & USA & Leaf of A. сера & + & $269 \mathrm{bp}$ \\
\hline BS7 & 3 & B3808 & UK & А. сера & + & $269 \mathrm{bp}$ \\
\hline BS8 & 3 & B3834 & UK & A. сера & + & $269 \mathrm{bp}$ \\
\hline BS9 & 6 & MD-16 & USA & А. сера & + & $269 \mathrm{bp}$ \\
\hline BS10 & 6 & $64 \mathrm{~A}$ & USA & A. сера & + & $269 \mathrm{bp}$ \\
\hline BS11 & 2 & MUCL 1107 & USA & Bulb of A. серa & + & $269 \mathrm{bp}$ \\
\hline B. porri & 7 & 1883 & $\ldots$ & $\ldots$ & + & $\ldots$ \\
\hline B. calthae & 7 & 1673 & $\ldots$ & $\ldots$ & + & $\ldots$ \\
\hline B. tulipae & 7 & 1890 & $\ldots$ & $\begin{array}{l}\ldots \\
\ldots\end{array}$ & + & $\ldots$ \\
\hline B. convoluta & 7 & 1375 & Norway & Iris pseudacorus & + & $\ldots$ \\
\hline Ciboria caucus & 7 & 1572 & Norway & Salix cyprea & + & $\ldots$ \\
\hline Cladosporium sp. & 1 & $\mathrm{C} 01$ & Denmark & Bulb of $A$. серa & + & $\ldots$ \\
\hline Clonostachys rosea & 1 & 201 & Denmark & Lycopersicon esculentum & + & $\ldots$ \\
\hline C. rosea & 8 & IK726 & Denmark & Soil & + & $\ldots$ \\
\hline Fusarium sp. & 1 & F01 & Denmark & Bulb of A. cepa & + & $\ldots$ \\
\hline Monilinia fructicola & 7 & 782 & Canada & Prunus persica & + & $\ldots$ \\
\hline M. fructigena & 7 & 1079 & Norway & P. domesticus & + & $\ldots$ \\
\hline M. laxa & 7 & 1083 & Norway & P. avium & + & $\ldots$ \\
\hline Myriosclerotinia ciborium & 7 & 1831 & & & + & $\ldots$ \\
\hline Penicillium sp. & 1 & P03 & Denmark & Bulb of A. cepa & + & $\ldots$ \\
\hline Sclerotinia sclerotiorum & 7 & 926 & Norway & Ranunculus ficaria & + & $\ldots$ \\
\hline Sclerotium cepivorum & 7 & 1878 & & $\ldots$ & + & $\ldots$ \\
\hline Trichoderma harzianum & 8 & $\mathrm{~T} 3$ & Denmark & $\ldots$ & + & $\ldots$ \\
\hline Ulocladium atrum & 9 & 385 & Holland & Leaf of A. cepa & + & $\ldots$ \\
\hline U. atrum & 1 & 302 & Denmark & Daucus carota & + & $\ldots$ \\
\hline U. consortiale & 1 & 303 & Denmark & Chrysanthemum seed & + & $\ldots$ \\
\hline U. botrytis & 1 & 304 & Denmark & Chrysanthemum seed & + & $\ldots$ \\
\hline 1, Danish Institute of Agric & Iral Science & s, Research Cen & kkebjerg, 420 & e, Denmark; 2, Belgium C & nated Collection o & roorganisms, Universit \\
\hline 1, Danisn institute or Agr & & & & , Denmark, , , Belguum & lated Comection c $^{2}$ & $\begin{array}{l}\text { roorganisms, Universit } \\
\text { voor Schimmelcultures }\end{array}$ \\
\hline & & & & Laboratories, Shionogi \& & $K$ late $\mathrm{s}$ & 024 Jon 6 Jorb \\
\hline nevitu 1941 Frodori & & 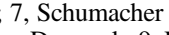 & . & ern, 0316 Oslo, Norway; & $\operatorname{sen} \mathrm{D}, \mathrm{Ro}$ & erinary and Agricultura \\
\hline University, 1841 Frederikst & , Copenhag & en, Denmark; 9,1 & , IPO-DLO, W & en, Holland. & & \\
\hline b Polymerase chain reaction & CR) ampli & ication of the IT & ion with prim & and TS4 was performed & ositive control of & NA. A $S p h$ I restrictior \\
\hline $\begin{array}{l}\text { digest of the PCR product } \\
\text { Size of diagnostic band af }\end{array}$ & $\begin{array}{l}\text { done for } \\
\text { oI restri }\end{array}$ & $\begin{array}{l}\text { aclada Al, } B \text {. } \\
\text { on digest of PC }\end{array}$ & $\begin{array}{l}\text { All, and } B . \\
\text { lification pr }\end{array}$ & $\begin{array}{l}\text { isolates. } \\
\text { a primer } \mathrm{BA} 2 \mathrm{f} \text { and } \mathrm{BA} 1 \mathrm{r} \text {. }\end{array}$ & & \\
\hline & & & 年 & & & \\
\hline
\end{tabular}


lated with $5 \mu \mathrm{l}$ of $B$. aclada (BA1) spore suspension $\left(10^{5}\right.$ spores per $\left.\mathrm{ml}\right)$, and incubated at $21^{\circ} \mathrm{C}$ under near UV light. Samples for DNA extraction were collected after 7 days of incubation.

For production of onion leaf pieces, three onion sets ('Hyton F1') were planted per $15-\mathrm{cm}$ pot containing a soil-peat-sand mix, and grown in a greenhouse for 8 weeks. They were watered as necessary. At harvest, leaves were cut into 1 - to $2-\mathrm{cm}$ pieces with a knife, freeze-dried, and leaf pieces placed in plastic bags and sealed. Plastic bags with leaf pieces were irradiated (absorbed dose: $1.1 \times 10^{6} \mathrm{rad}$ ) for sterilization and stored in the dark at $22 \pm$ $2{ }^{\circ} \mathrm{C}$ until use. Five leaf pieces were aseptically placed in a $9-\mathrm{cm}$ petri dish containing a sterile glass filter paper (MN615; MachereyNagel, Düren, Germany), and $1 \mathrm{ml}$ of sterile $\mathrm{H}_{2} \mathrm{O}$ was added. Each leaf piece was inoculated with $5 \mu \mathrm{l}$ of $B$. aclada (BA1) spore suspension $\left(10^{5}\right.$ spores $\left.\mathrm{ml}^{-1}\right)$, except for noninoculated controls. At $0,24,48,96$, and $144 \mathrm{~h}$ after inoculation, five leaf pieces were randomly collected for DNA extraction. Control leaves that had not been inoculated were collected after 6 days $(144 \mathrm{~h})$. The experiment was performed twice.

DNA extraction from fungal mycelium. Fungi were grown for 5 to 7 days at $21^{\circ} \mathrm{C}$ in the dark on PDA covered with a dry-sterilized $\left(120^{\circ} \mathrm{C}\right.$ for $\left.12 \mathrm{~h}\right)$ disk of cellophane. Mycelia were scraped from the cellophane with a sterile scalpel and ground in liquid nitrogen using a mortar and pestle. Powdered mycelium (30 mg) was transferred to an Eppendorf tube, and DNA was extracted using the CTAB method (13). DNA was dissolved in $50 \mu \mathrm{l}$ of TE (10 mM Tris-HCl, $1 \mathrm{mM}$ EDTA, $\mathrm{pH}$ 8.0) buffer and stored at $-20^{\circ} \mathrm{C}$ until use. DNA concentration of $B$. aclada isolate BA1 was estimated with the aid of agarose gels and adjusted to $0.1 \mu \mathrm{g} \mu \mathrm{l}^{-1}$. Concentra- tions for all other isolates were within the range of $0.01 \mu \mathrm{g} \mu \mathrm{l}^{-1}$ to $0.1 \mu \mathrm{g} \mathrm{l}^{-1}$. For use in PCR analysis, DNA samples were diluted 10-fold. For determination of sensitivity of the PCR method, dilution series of BA1 DNA were made in the range from

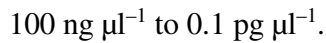

DNA extraction from plant tissue. $B$. aclada-infected onion tissues (bulbs, mature leaves) were collected with sterile forceps and scalpels. Each tissue sample $(0.05-0.15 \mathrm{~g})$ was placed in a plastic tube containing FastDNA Lysing Matrix, a 6.4$\mathrm{mm}(0.25$-in) ceramic sphere and a $6.4-\mathrm{mm}$ (0.25-in) ceramic cylinder (BIO 101, Inc., Vista, CA), and frozen at $-20^{\circ} \mathrm{C}$ until use. For DNA extraction, $600 \mu \mathrm{l}$ of PEX buffer (100 mM Tris/HCl (pH 8.5), $10 \mathrm{mM}$ EDTA, $700 \mathrm{mM} \mathrm{NaCl}, 6.25 \mathrm{mM}$ potassium ethyl xanthogenate) (2) was added to the tube, and the onion tissue was then homogenized in a FastPrep Instrument (FP120; BIO 101) at speed setting 5 for 20 s. After the homogenization, the tubes were incubated at $65^{\circ} \mathrm{C}$ for $1 \mathrm{~h}$. Phenolchloroform-isoamylalcohol (12:12:1) was added $(600 \mu \mathrm{l})$, and the tubes were hand mixed for $5 \mathrm{~s}$, then placed on ice for $5 \mathrm{~min}$. After centrifugation for $10 \min (10,000 \times g$ at $4^{\circ} \mathrm{C}$ ), the supernatant carrying the DNA was transferred to a new tube. DNA was precipitated by adding $60 \mu \mathrm{l}$ of $3 \mathrm{M} \mathrm{Na}-$ acetate, $\mathrm{pH} 4.8$, and $600 \mu \mathrm{l}$ of isopropanol. The contents were mixed by inverting the tubes, incubated $10 \mathrm{~min}$ on ice, and centrifuged for $10 \mathrm{~min}\left(13,000 \times g\right.$ at $\left.4^{\circ} \mathrm{C}\right)$. The supernatant was removed and the pellet was rinsed with $500 \mu \mathrm{l}$ of $70 \% \mathrm{EtOH}$, vacuum dried for 10 to $15 \mathrm{~min}$, dissolved in $100 \mu \mathrm{l}$ of TE buffer $(1 \mathrm{mM}$ Tris/ $\mathrm{HCl}, \mathrm{pH}$ 7.8, 0.1 mM EDTA), and stored at $-20^{\circ} \mathrm{C}$ until use. DNA was used directly for PCR analysis without dilution.

Design of primers and restriction analysis. In a previous study of Botrytis

Table 2. Nucleotide sequences of primers used in this study

\begin{tabular}{llllc}
\hline Name & Application & Nucleotide sequence $\left(\mathbf{5}^{\prime}-\mathbf{3}^{\prime}\right)$ & Product & Reference \\
\hline ITS1 & ITS amplification & TCCGTAGGTGAACCTGCGG & $\approx 550 \mathrm{bp}$ & 28 \\
ITS4 & ITS amplification & TCCTCCGCTTATTGATATGC & & 28 \\
BA2f & Botrytis amplification & GTGGGGGTAGGATGAGATGATG & $\approx 413 \mathrm{bp}$ & This paper \\
BA1r & Botrytis amplification & TGAGTGCTGGCGGAAACAAA & & This paper \\
\hline
\end{tabular}

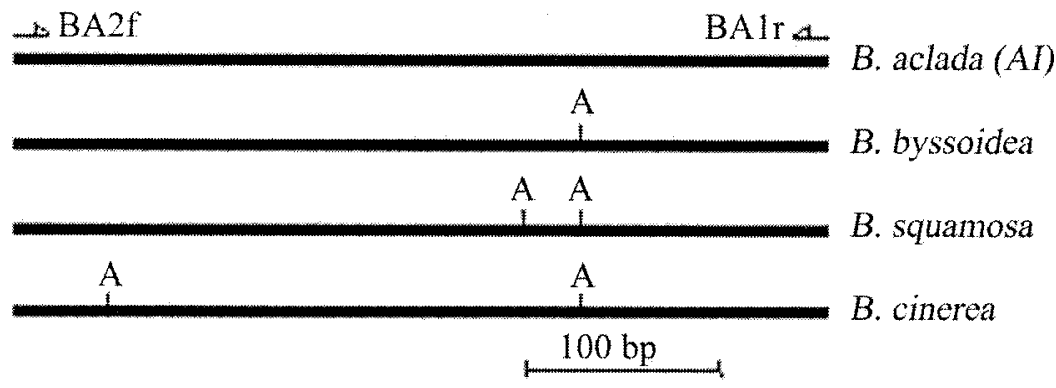

Fig. 1. Restriction map of the BA2f-BA1r polymerase chain reaction (PCR)-amplified fragment for Botrytis spp. causing disease in onions. B. aclada type AII isolates contain both the B. aclada type $\mathrm{AI}$ and the B. byssoidea DNA types. Arrows indicate primers (BA2f and BA1r) used for PCR amplification. A: ApoI restriction endonuclease cleavage sites. isolates, a UP-PCR DNA fragment, L45550 , was cloned and sequenced (19). Based on these sequences (GenBank accession numbers: AJ291476-AJ291487), two sequence characterized amplified region (SCAR) primers (BA2f/BA1r; Table 2) were designed using the program PrimerSelect in the program package DNASTAR (Windows 32 PrimerSelect 4.00, 1993-1999 DNASTAR Inc.) that amplify a 413-bp PCR product in the five Botrytis groups associated with onion diseases. An analysis of restriction enzyme cleavage sites in the sequences of $B$. cinerea, B. squamosa, B. byssoidea, and $B$. aclada type AI revealed that a restriction digest with ApoI would make it possible to differentiate among the four Botrytis species (Fig. 1).

PCR amplification. PCR amplification was performed in a total reaction volume of $20 \mu \mathrm{l}$. The following compounds were added, with final concentrations indicated: $\mathrm{MgCl}_{2}(2.5 \mathrm{mM})$, dNTP $(0.25 \mathrm{mM}$ of each dATP, dGTP, dCTP, dTTP), Taq DNA polymerase (1 unit) (Promega, Madison, WI), KCl (50 mM), Tris-HCl, pH 9.0 (10 mM), Triton X-100 $(0.1 \%), 0.5 \mathrm{pmol} \mathrm{l}^{-1}$ of each primer (Table 2), and $10 \mathrm{ng}-100 \mathrm{ng}$ of fungal DNA were added as template. A GeneAmp PCR System 9700 (Perkin Elmer, Norwalk, CT) thermo-cycler device was used with the following program: $94^{\circ} \mathrm{C}$ (3 min), 1 cycle; $\left(94^{\circ} \mathrm{C}\right.$ [30 s], $53^{\circ} \mathrm{C}$ or $60^{\circ} \mathrm{C}$ [30 s], $72^{\circ} \mathrm{C}$ [ $\left.\left.1 \mathrm{~min}\right]\right), 29$ cycles; $72^{\circ} \mathrm{C}(3$ min), 1 cycle. The annealing temperatures of $53^{\circ} \mathrm{C}$ and $60^{\circ} \mathrm{C}$ were used for amplification of the internal transcribed spacer (ITS) region and for the Botrytis-specific amplification, respectively. The PCR product $(3 \mu \mathrm{l})$ was separated in $1.5 \%$ agarose (Sigma) gels in $1 \times$ TAE $(40 \mathrm{mM}$ Tris-acetate, 1 mM EDTA, $\mathrm{pH}$ 8.0), stained with ethidium bromide, and visualized under UV light. PCR amplification of fungal isolates with the Botrytisspecific primer pair BA2f/BA1r was performed at least twice.

Restriction analysis. Presence of an ITS amplification PCR product was used as a control of the DNA quality for all isolates. $B$. aclada, $B$. byssoidea, $B$. squamosa, and $B$. cinerea isolates were further tested by restriction analysis of the

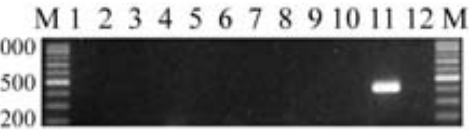

Fig. 2. Polymerase chain reaction (PCR) amplification with BA2f-BA1r. M: 100-bp ladder, with uppermost band 1,000 bp; 1: Ulocladium atrum $302 ; 2: U$. consortiale $303 ; 3: U$. botrytis 304; 4: U. atrum 385; 5: Clonostachys rosea 201; 6: C. rosea IK726; 7: Trichoderma harzianum T3; 8: Penicillium sp. P03; 9: Cladosporium sp. C01; 10: Fusarium sp. F01; 11: Botrytis aclada BA1; 12: negative control. 
ITS amplicon. The PCR amplification product $(2 \mu \mathrm{l})$ was digested, without prior purification, with $S p h \mathrm{I}$ (New England Biolabs Inc., Beverly, MA) in a total volume of $10 \mu \mathrm{l}$ according to the manufacturer's recommendation. After restriction digestion, the DNA products $(5 \mu \mathrm{l})$ were separated on a $1.5 \%$ agarose gel, stained with ethidium bromide, and visualized under UV light. BA2f/BA1r PCR amplification product $(2 \mu \mathrm{l})$ was digested with ApoI (New England Biolabs) without further purification, as described above. The restriction analysis of Botrytis isolates was performed several times.

\section{RESULTS}

PCR amplification. Botrytis neck rotassociated isolates, originating from Europe, the United States, Egypt, and Asia were amplified with the Botrytis-specific primer pair (BA2f/BA1r), giving an amplification product of $413 \mathrm{bp}$. Botrytis isolates nonpathogenic to onions and isolates of other fungi were amplified with ITS primers but not with the BA2f/BA1r primer pair (Fig. 2). An ApoI restriction digest of the PCR amplification product (Fig. 3) separated the five groups of Botrytis causing disease in onions. All B. aclada (AII) isolates contained the sum of the bands found in B. aclada (AI) and B. byssoidea. To determine if the mixed restriction pattern is a result of the presence of B. aclada (AII) alone or is the result of a mixture of B. aclada (AI) and B. byssoidea, a restriction analysis of the ITS region was performed. B. aclada (AI) yielded three fragments (223, 200, and 116 bp) after a SphI

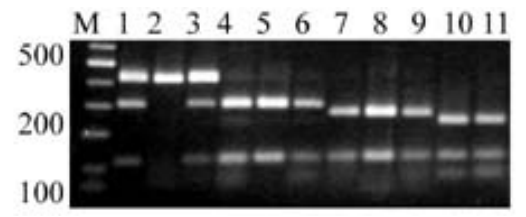

Fig. 3. ApoI restriction digest of BA2f-BA1r polymerase chain reaction (PCR) amplification product. M: 100-bp ladder, where uppermost band is $500 \mathrm{bp}$; 1: Botrytis aclada BA4 (type AII); 2: BA1 (type AI); 3: BA5 (type AII); $4: B$. byssoidea BB1; 5: BB5; 6: BB6; 7: $B$. squamosa $\mathrm{BS} 2$; 8: BS6; 9: BS7; 10: B. cinerea $\mathrm{BC} 1 ; 11: \mathrm{BC} 3$. digest of the ITS amplification product, whereas B. aclada (AII) and B. byssoidea both yielded two fragments of 316 and 223 bp (Fig. 4).

DNA extraction. Use of the PEX buffer for DNA extraction from inoculated onion tissue avoided foaming during tissue maceration and allowed for easy mixing with phenol-chloroform afterwards. No differences in DNA concentration or purity between the PEX-extracted DNA and the CTAB-extracted DNA were observed (data not shown).

Sensitivity of BA2f/BA1r amplification. Dilution series of the B. aclada isolate BA1 DNA showed that 1 to $10 \mathrm{pg}$ of pure fungal DNA could be detected (Fig. 5). B. aclada was amplified using the BA2f/BA1r primer pair in all 20 samples of onion scales inoculated with B. aclada. No PCR product was observed in the noninoculated controls. At $48 \mathrm{~h}$ postinoculation, there were no visible signs of Botrytis infection on leaf pieces, whereas $B$. aclada was detected by PCR in six of six dead leaf pieces (Fig. 6).

\section{DISCUSSION}

The Botrytis specific primer pair BA2f/BA1r amplified all neck rotassociated Botrytis isolates used in this study. A restriction digest of the amplification product with ApoI separated the Botrytis isolates into five groups: $B$. aclada types AI and AII; $B$. byssoidea; $B$. squamosa; and $B$. cinerea. DNA was not amplified using the BA2f/BA1r primers from any other species tested. Among the other species tested were isolates of: Sclerotium cepivorum, causal agent of white rot in onions; Penicillium spp., represent-

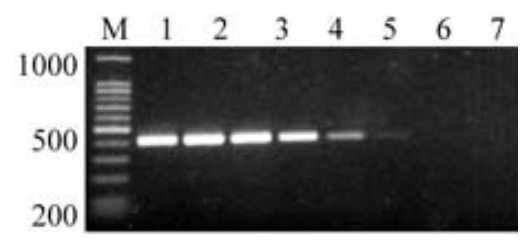

Fig. 5. Sensitivity of BA2f-BA1r polymerase chain reaction (PCR) amplification of Botrytis aclada BA1 DNA. M: 100-bp ladder; 1: 100 $\mathrm{ng} ; 2: 10 \mathrm{ng}$; 3: $1 \mathrm{ng} ; 4: 100 \mathrm{pg} ; 5: 10 \mathrm{pg} ; 6: 1$ pg; 7: $100 \mathrm{fg}$.

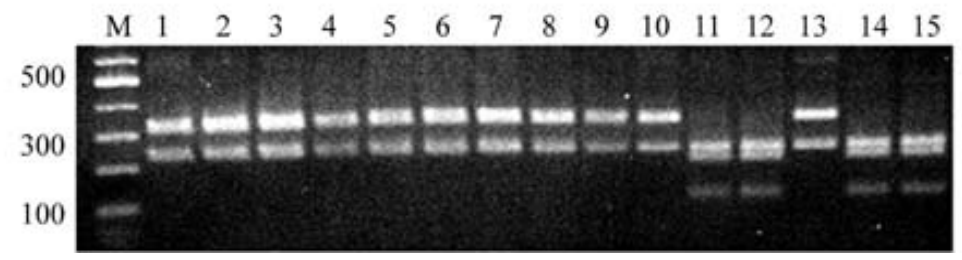

Fig. 4. SphI restriction digest of the internal transcribed spacer (ITS) polymerase chain reaction (PCR) amplification product. M: 100-bp ladder, where uppermost band is $600 \mathrm{bp} ; 1:$ Botrytis cinerea (BC1); 2: BC3; 3: BC4; 4: BC6; 5: BC7; 6: B. byssoidea (BB1); 7: BB5; 8: BB6; 9: B. squamosa (BS2); 10: BS6; 11: B. aclada (BA1, type AI); 12: BA2 (type AI); 13: BA4 (type AII); 14: BA8 (type AI); 15: BA13 (type AI).

ing many common saprophytes and onion pathogens associated with blue mold of onions; Fusarium spp., which cause damping-off and basal rot in onions; Cladosporium sp., which causes leaf blotch on onions; and Sclerotinia sclerotiorum, causing rot of onions, as well as other non-neck rot-associated Botrytis species demonstrating the specificity of the primers to Botrytis onion neck rot-associated pathogens.

Different approaches (dependent on the fungal species) can be used to select suitable DNA sequences for designing specific primers. Nucleotide differences in the ITS region of the ribosomal genes have been used with success to design speciesspecific primers $(3,4,14)$. However, the variation in the ITS region within the genus Botrytis is very low $(17,18)$ and thus not suitable for designing species-specific primers. The $\beta$-tubulin gene has been used as a source of primers that differentiate between $B$. cinerea isolates that are susceptible or resistant to the fungicide benomyl (9). A third approach, and the strategy used in this paper, has been the use of sequence characterized amplified regions of random amplified DNA fragments for primer design $(15,20,21)$.

The detection limit for our primer pair was between 1 and $10 \mathrm{pg}$ of pure fungal DNA. This corresponds to the detection limit found by others using the SCAR procedure for designing specific primers (24). B. aclada was detected in onion leaf pieces $48 \mathrm{~h}$ after inoculation with conidia, at which time there was no visible infection. Moricca et al. (14) reported detection of 50 to $100 \mathrm{fg}$ of Fusarium oxysporum $\mathrm{f}$. sp. vasinfectum DNA, an apparent sensitivity 100 times greater that ours. However, their primers are based on ITS-rDNA sequences of which there are at least 100 copies within a genome.

Latent Botrytis infections in onions grown in microplots were detected in three of 60 leaf pieces using the PCR method, where standard isolation showed only one (D. S. Yohalem, unpublished data). The method also allows for assessment of infection prior to storage, which allows us to more quickly evaluate the efficacy of management strategies as well as the storage potential of the harvested crop. In a field experiment with high disease pressure, preliminary results based on 320 samples indicate a two- to threefold higher detection rate at harvest using the PCR-method

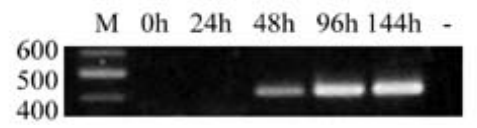

Fig. 6. Polymerase chain reaction (PCR) amplification of Botrytis aclada BA1 inoculated (500 spores) on $1.5 \times 1.5 \mathrm{~cm}$ onion leaf pieces and prior DNA extraction incubated in a moist chamber for $0,24,48,96$, and $144 \mathrm{~h}$. Control = uninoculated leaf piece, M: 100-bp DNA ladder, where uppermost band is $600 \mathrm{bp}$. 
compared with conventional culturing of adjacent tissues from onion necks (D. S. Yohalem, unpublished data), which suggests that the PCR detection method is more sensitive than isolation. The method may also prove useful in the evaluation of seed lots for infestation with neck rot pathogens.

In addition to detecting the presence of very small amounts of neck rot-associated Botrytis spp. in onion tissues, the present method enhances our ability to correctly diagnose the causal agent, particularly since both $B$. byssoidea and $B$. squamosa frequently fail to sporulate in culture. Differentiation among the various pathogens has important epidemiological implications and may affect management strategies.

\section{ACKNOWLEDGMENTS}

The present work was supported by the Danish Ministry of Agriculture: Biological and microbiological control of pests (1996-2000) program, Ecological Agricultural Program (FØJO I), and grants from the Danish Institute of Agricultural Sciences. We thank M. Masuko, S. R. Kenny, J. W. Lorbeer, and T. Schumacher for providing fungal isolates for this investigation.

\section{LITERATURE CITED}

1. Anonymous. 2001. Testing onion seed for diseases. Onion World May/June:11.

2. Edwards, S. G., Fitter, A. H., and Young, J. P. W. 1997. Quantification of an arbuscular mycorrhizal fungus, Glomus mosseae, within plant roots by competitive polymerase chain reaction. Mycol. Res. 101:1440-1444.

3. Förster, H., and Adaskaveg J. E. 2000. Early brown rot infections in sweet cherry fruit are detected by Monilinia-specific DNA primers. Phytopathology 90:171-178.

4. Hamelin, R. C., Bérubé, P., Gignac, M., and Bourassa, M. 1996. Identification of root rot fungi in nursery seedlings by nested multiplex PCR. Appl. Environ. Microbiol. 62:4026-4031.

5. Hennebert, G. L. 1963. Les Botrytis des Allium. Meded. LandbHoogesch. OpzoekStns. Gent 28:851-876.
6. Hennebert, G. L. 1973. Botrytis and Botrytislike genera. Persoonia 7:183-204.

7. Lacy, M. L., and Lorbeer, J. W. 1995. Botrytis neck rot. Pages 18-19 in: Compendium of Onion and Garlic Diseases. H. F. Schwartz and S. K. Mohan, eds. American Phytopathological Society, St. Paul, MN.

8. Linfield, C. A., Kenny, S. R., and Lyons, N. F. 1995. A serological test for detecting Botrytis allii, the causal agent of neck rot of onion bulbs. Ann. Appl. Biol. 126:259-268.

9. Luck, J. E., and Gillings, M. R. 1995. Rapid identification of benomyl resistant strains of Botrytis cinerea using the polymerase chain reaction. Mycol. Res. 99:1483-1488.

10. Maude, R. B. 1988. Ascomycetes V: Botrytis allii. Pages 431-432 in: European Handbook of Plant Diseases. I. M. Smith, J. Dunez, R. A. Lelliott, D. H. Phillips, and S. A. Archer, eds. Blackwell Scientific Publications, Oxford.

11. Maude, R. B., and Presly, A. H. 1977. Neck rot (Botrytis allii) of bulb onions. I. Seedborne infection and its relationship to the disease in the onion crop. Ann. Appl. Biol. 86:163-180.

12. Maude, R. B., and Presly, A. H. 1977. Neck rot (Botrytis allii) of bulb onions. II. Seedborne infection in relationship to disease in store and the effect of seed treatment. Ann. Appl. Biol. 86:181-188.

13. Möller, E. M., Bahnweg, G., Sandermann, H., and Geiger, H. H. 1992. A simple and efficient protocol for isolation of high molecular weight DNA from filamentous fungi, fruit bodies, and infected plant tissues. Nucleic Acids Res. 20:6115-6116.

14. Moricca, S., Ragazzi, A., Kasuga, T., and Mitchelson, K. R. 1998. Detection of Fusarium oxysporum $\mathrm{f}$. $\mathrm{sp}$. vasinfectum in cotton tissue by polymerase chain reaction. Plant Pathol. 47:486-494.

15. Nicholson, P., and Parry, D. W. 1996. Development and use of a PCR based assay to detect Rhizoctonia cerealis, the causal agent of sharp eyespot in wheat. Plant Pathol. 45:872883.

16. Nielsen, K. 2000. Molecular characterisation and biological control of grey mould (Botrytis spp.) in onion. Ph.D. thesis. The Royal Veterinary and Agricultural University, Copenhagen, Denmark.

17. Nielsen, K., Justesen, A. F., Jensen, D. F., and
Yohalem, D. S. 2001. Universally primed polymerase chain reaction alleles and internal transcribed spacer restriction fragment length polymorphisms distinguish two subgroups in Botrytis aclada distinct from $B$. byssoidea. Phytopathology 91:527-533.

18. Nielsen, K., Justesen, A. F., and Yohalem, D. S. 1999. PCR based detection of latent infections of Botrytis aclada Fres. in onion bulbs. Petria 9:105-108.

19. Nielsen, K., and Yohalem, D. S. 2001. Origin of a polyploid Botrytis pathogen through interspecific hybridization between Botrytis aclada and B. byssoidea. Mycologia 93:264271.

20. Paran, I., and Michelmore, R. W. 1993. Development of reliable PCR-based markers linked to downy mildew resistance genes in lettuce. Theor. Appl. Genet. 85:985-993.

21. Parry, D. W., and Nicholson, P. 1996. Development of a PCR assay to detect Fusarium poae in wheat. Plant Pathol. 45:383-391.

22. Presly, A. H. 1985. Methods for inducing sporulation of some Botrytis species occurring on onions and leeks. Trans. Br. Mycol. Soc. 85:621-624.

23. Presly, A. H. 1985. Studies of Botrytis spp. occurring on onions (Allium cepa) and leeks (Allium porrum). Plant Pathol. 34:422-427.

24. Schena, L., Sialer, M. F., and Gallitelli, D. 2002. Molecular detection of strain L47 of Aureobasidium pullulans, a biocontrol agent of postharvest diseases. Plant Dis. 86:54-60.

25. Shirane, N., Masuko, M., and Hayashi, Y 1989. Light microscopy observation of nuclei and mitotic chromosomes of Botrytis species. Phytopathology 79:728-730.

26. Tichelaar, G. M. 1967. Studies on the biology of Botrytis allii on Allium cepa. Neth. J. Plant Pathol. 73:157-160.

27. Walker, J. C. 1925. Two undescribed species of Botrytis associated with the neck rot disease of onion bulbs. Phytopathology 15:708 713.

28. White, T. J., Bruns, T., Lee, S., and Taylor, J. W. 1990. Amplification and direct sequencing of fungal ribosomal RNA genes for phylogenetics. Pages 315-322 in: PCR Protocols, A Guide to Methods and Applications. M. A. Innis, D. H. Gelfand, J. J. Sninsky, and T. J. White, eds. Academic Press, San Diego. 